\title{
Lesson Study as an Intervention to Develop Prospective English Language Teachers' Classroom Management Skills
}

\author{
Ertan Altınsoy \\ ○https://orcid.org/0000-0002-8638-744X \\ Aksaray Üniversitesi, Turkey \\ *e-mail: ertanaltinsoy@gmail.com
}

\begin{abstract}
Article Information
Received: April 30, 2021

Revised: June 16, 2021

Accepted: June 20, 2021

Online: August 16, 2021
\end{abstract}

\section{Keywords}

Classroom management; Lesson

Study; preservice ELT teachers

\begin{abstract}
This study investigated six pre-service ELT teachers' engagement of collaborative Lesson Study, Japanese professional development model, and intended to explore its impact on their classroom management skills. The qualitative research design was used as the methodological foundation of the study since the Lesson Study experience of the participants was thoroughly observed in its natural context through research lesson applications. The large volume of data collected using a variety of data collection tools was analyzed using Atlas. Ti qualitative software. The study revealed that Lesson Study intervention impacted the participants' classroom management skills in various dimensions at varying degrees, especially in increasing awareness about the observation of student learning, giving instructions, and lesson planning aspects. The study further presented that Lesson Study provides a reformist professional development opportunity for pre-service teachers to practice various classroom management strategies in various actual classroom settings.
\end{abstract}

\section{INTRODUCTION}

Teaching has always been a multifaceted and complex phenomenon that requires a delicate balance between planning and effective implementation of instruction by managing students' behaviors skillfully to keep students on task with constant focus. This balance is so fragile that it causes significant challenges and concerns, especially for the beginning teachers (Roberts, 1998). Classroom management which has been considered one of the primary components of effective classroom instruction, has been the central concern of the prospective teachers (Balli, 2011; Martin, 2004; Poulou, 2007; Reupert \& Woodcock, 2010;). There is a growing body of research documenting that pre-service teachers lack necessary classroom management skills and they are unprepared to deal with issues concerning classroom management which interfere with student learning and cause a great deal of stress and anxiety ( (Dicke, Elling, Schmeck, \& Leutner, 2015; Hoy \& Weinstein, 2006; Jones, 2006; Kang \& Cavanagh, 2018). Effective classroom management is vital for an ideal classroom environment that promotes student learning and achievement. In this sense, literature has acknowledged that classroom management is the most valuable skill set that teacher candidates may possess (Landau, 2001).

However, despite its significance as a critical skill, literature has acknowledged that most teacher training programs lack systematic and comprehensive training on classroom management (Wesley \& Vocke, 1992). This lack of attention and focus has placed classroom management at the low end of priorities and pedagogical innovation, as Eisenman, Edwards, and Cushman (2015) suggested. Another critical issue is that the limited training on classroom management is essentially too theoretical for the 
prospective teachers and disconnected from the actual classroom environment ( Although recent studies have reported the positive effects of computer-based classroom simulations on classroom management and teaching skills of the pre-service teachers (Theelen, van den Deemt, \& den Brok, 2018; Hudson, Voytecki, Owens, \& Zhang, 2019), it has been acknowledged that prospective teachers complete teacher training without fully accomplishing in classroom management because of the gap between theory and practice in terms of classroom management skills ( this respect, pre-service teachers have been left unguarded in managing student behaviors when they start the profession and are expected to develop classroom management skills with experience, which significantly cause classroom management problems leading to stress and burnout symptoms. Therefore, teacher education programs should ensure necessary content knowledge and equip prospective teachers with a wider repertoire of classroom management skills crucial for maintaining the best learning environment for the learners.

In order to bridge the gap, efforts have been paid by providing in-service-classroom management programs and professional development programs for the beginning teachers to alleviate classroom management concerns which have been reported to have a significant positive impact on the classroom management skills of the prospective teachers (Baker, Gentry, \& Larmer, 2016; Christofferson \& Sullivan, 2015; Dicke, Elling, Schmeck, \& Leutner, 2015). However, those programs are limited in number and scope (Hammerness, 2011). In this sense, the consensus is that teacher training courses should provide extended field-based experiences directly addressing classroom management issues by exposing student teachers to multiple classroom cases that stimulate a reflective problem-solving approach (Adler, 1991; Flower, McKenna, \& Haring, 2017; Stoiber, 1991). It was argued that such a casebased reflective approach in which pre-service teachers provide a reason for their practices and interventions leads to developing a more conceptual framework about classroom management (Adler, 1991). Within this perspective, the present study adapted the Japanese professional development model "Lesson Study" (LS) into pre-service language teacher education to investigate if LS makes a difference in the classroom management skills of the participants.

\section{Literature Review}

Lesson Study is a collaborative professional development model originated in Japan and is based on the collective examination of teaching practice as the Japanese term "jugyokenkyu" denotes (Fernandez \& Yoshida, 2004). According to Dudley (2015), LS is the recent fastest-growing approach that contributes significantly to teacher learning, substantially impacting student learning (p. 4). Today LS has become a global phenomenon practiced at a national and international level in the 21st century. Figure 1 below displays typical LS cycle steps.

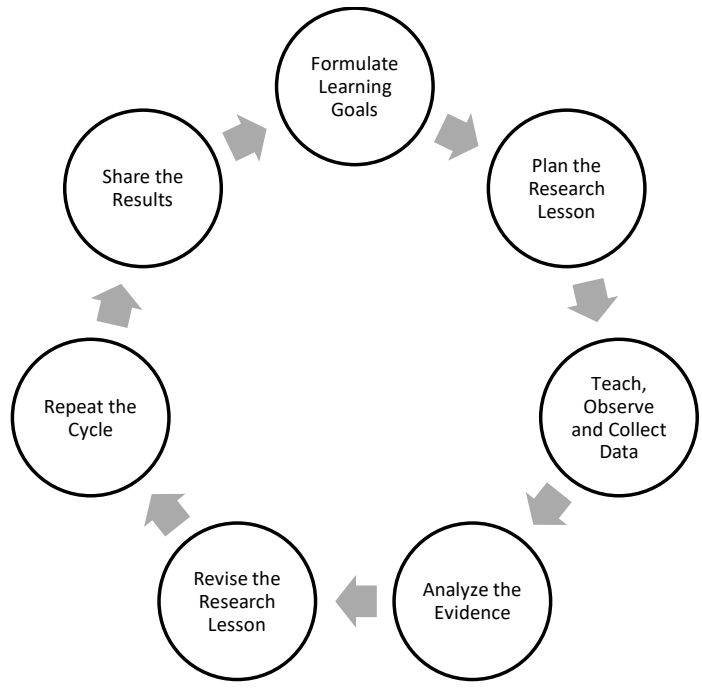

Figure 1. Lesson Study Cycle (Adapted from the Sequence of Steps in the Lesson Study Cycle by Cerbin, 2011, p.5) 
LS is a form of systematic practitioner inquiry and has a cyclical process split into recurring steps of collaborative planning of a research lesson, teaching it, and investigating the research lesson based on the collected data (Cerbin, 2011). In this respect, LS is fundamentally based on sharing professional knowledge derived from reflective thinking that is thinking beyond the experiences to make meaning of one's action.

It has been documented in the literature that LS is a vital tool for the pre-service teachers to connect theory and practice (Fernandez \& Robinson, 2006; Murata \& Pothen, 2011), which has been reported as the primary deficiency in most teacher training programs (Allen, 2009; Freeman, 2002; Richards, 2008). There is a growing body of research investigating the effectiveness of LS in teacher training programs and providing solid evidence supporting the professional development of prospective teachers (Fernandez, 2010; Leavy \& Hourigan, 2016; Sims \& Walsh, 2009).

For example Murata and Pothen (2011), reported that the participating pre-service teachers gained various critical pedagogical skills through LS, which supported connection building and a sensemaking process between theory and practice. In a longitudinal study, Fernandez and Robinson (2006) integrated LS into microteaching and observed that LS helped connect theory and practice and stimulated engagement in and learning about reflection. In another longitudinal study, Sims and Walsh (2009) documented that LS helped pre-service teachers become more reflective and self-critical, and the process contributed significantly to their instructional strategies. More recently, Angelini and Alvarez (2018) reported that LS reinforced the pre-service teachers' classroom management skills, which improved their ability to teach in the classroom.

Within this context, in the present study, the Japanese LS professional development model was adapted into pre-service language teacher education in Turkey to investigate if LS makes a difference and impacts the classroom management skills of the participating pre-service ELT teachers. Therefore, the following research question and sub-question guided the inquiry for the present study.

1. Does Lesson Study have an impact on the participants' classroom management skills in terms of teacher interventions?

2. If so, how does each participant perceive the impact of Lesson Study on their classroom management skills?

\section{METHODS}

Creswell (2012), in his comprehensive book on the qualitative research inquiry, summarizes the characteristics of qualitative research design as natural settings, researcher as a critical instrument, multiple sources of data, inductive data analysis, participants meanings, and interpretative inquiry. In line with this, qualitative research inquiry was selected as the research design for the present study as it aims to investigate a complex phenomenon called LS in its natural context. Also, the researcher has a crucial role in LS applications as he contributes to the process as a guide and knowledgeable person during planning, application, and evaluation of the research lessons. Moreover, LS provides rich data from various sources, including lesson planning meetings, research lesson observations, and post-lesson discussions. Additionally, the cyclical process in research lesson applications requires descriptive and conceptual level analysis of the collected data, leading to bottom-up processing in the interpretation of data.

The study also employs case study design since the impact of LS on the classroom management skills of the participants are observed thoroughly in multiple cases through research lesson applications, as suggested by Creswell (2012).

Since the distinctive feature of LS is the collaborative efforts of participants to reach an overarching goal, the participants were scaffolded by a more experienced professional, the researcher, and an outside specialist. The researcher organized the Lesson Study team and provided necessary training on the implementation of research lessons. An outside expert specializing in curriculum and instruction participated in the research process to provide assistance when needed and thus enhance the pre-service ELT teachers' LS experience.

Six participants from Aksaray University were purposively recruited for this study. They were within the age range of 22-27 years old. The participants comprise five females and one male. There was no equal distribution among participants in terms of gender as gender variable was not guiding the inquiry as a research question. Informed consent was received from the participants who declared their 
willingness to participate in the study. Also, ethical approval (number 2016/45-69) was obtained from the university ethical committee before the commencement of the study. All participants did not have any professional teaching experiences as language teachers before.

The present LS study consisted of five research lesson applications. Each application was conducted in different public schools located within the regions of Aksaray province. The following table includes details about the research lesson school and classrooms. Because of ethical concerns, schools' names were provided with acronyms.

Table 1. Research Context

\begin{tabular}{|c|c|c|c|c|c|c|}
\hline $\begin{array}{l}\text { Research } \\
\text { Lessons }\end{array}$ & School & Location & Type & $\begin{array}{c}\text { Classroom } \\
\text { Layout }\end{array}$ & Grade & $\begin{array}{c}\text { Number of } \\
\text { Students }\end{array}$ \\
\hline Pilot Study & $\begin{array}{l}\text { P.M.P. Secondary } \\
\text { School }\end{array}$ & City-Centre & Public & Traditional & 7 & 24 \\
\hline 2 & $\begin{array}{l}\text { H. C. Ü. } \\
\text { Secondary } \\
\text { School }\end{array}$ & City-Centre & & & & 30 \\
\hline 3 & $\begin{array}{l}\text { Y.H.B. Secondary } \\
\text { School }\end{array}$ & Suburb & & & & 30 \\
\hline 4 & $\begin{array}{l}\text { H. C. U. } \\
\text { Secondary } \\
\text { School }\end{array}$ & Suburb & & & & 12 \\
\hline 5 & $\begin{array}{l}\text { M. T. E. } \\
\text { Secondary } \\
\text { School }\end{array}$ & $\begin{array}{l}\text { City-Centre + } \\
\text { Suburb }\end{array}$ & & & & 25 \\
\hline
\end{tabular}

The table visualizes that the research lessons were implemented at several schools in which the students come from different socio-economic backgrounds and academic levels to obtain more reliable data and valid results.

LS process in the present study consisted of two stages, theoretical and practical. The theoretical phase was intended to train the participants conceptually about the fundamentals of LS procedure, and it included a 5-week training period, each of which consisted of weekly meetings for approximately two hours under the researcher's supervision. The participants were informed about one specific aspect of LS application each week, which was informed by the comprehensive work of Cerbin (2011). The experimental stage consisted of one pilot study and four research lesson implementations in five different schools, which lasted for seven months.

The pilot study's purpose was to introduce LS to the participants in the practical sense and test the feasibility and applicability of the intervention. The participants were provided with necessary documents as a group goal selection document, lesson study protocol, and lesson plan template created by Ertle, Chokshi, and Fernandez (2012), and they decided on the overarching goal and prepared the first research lesson as a pilot study after two lengthy lesson planning meetings. Two post-lesson discussions were held after implementing the research lesson to discuss its efficacy based on observational records.

The same procedures were followed for the following four research lessons until the participants agreed that the overarching goal was attained and the pre-planned core research lesson objectives were reached. Each research lesson involved one or two lesson planning meetings, the application of the research lesson by an LS group member, and one or two post-lesson discussions depending on the observational records. The following diagram presents the steps taken during the LS implementation process. 


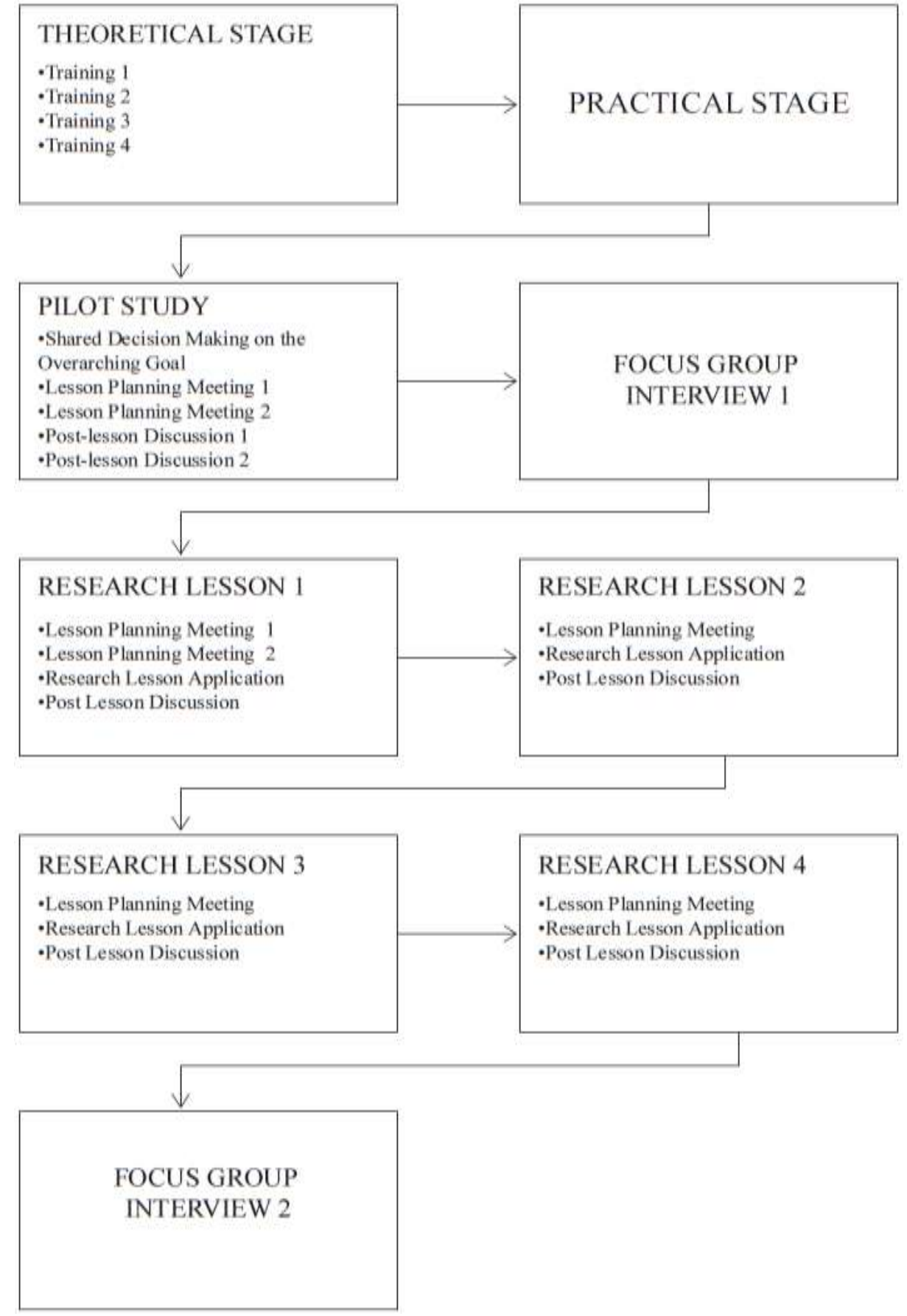

Diagram 1. Lesson Study Process

The large volume of data was collected from multiple sources because of the qualitative nature of the study in which the participants implemented LS in five real-life teaching cases. The sources of evidence included transcriptions of lesson planning meetings which were categorized as unstructured interviews, post-lesson discussions of each research lesson cycle that were labeled as semi-structured interviews, participants' classroom observation data that they took during the implementation of research lessons, reflective diaries written by the participants after each research lesson cycle that they critically reflected on their experiences, focus group interview data collected after pilot study and whole research process.

Unstructured interviews made up of the video recordings of lesson planning meetings for each research lesson. The participants discussed the research lesson content to address the overarching goal based on the template prepared by Ertle, Chokshi, \& Fernandez. The discussions centered around 
background information about the goal of the research lesson and research lesson school and students, information about the unit, its goals, its sequence and relation to the curriculum, information about the unit including goal(s) of the research lessons, its relation to the lesson study goals and process of the research lesson including steps of the research lesson with learning activities and time allocated for each, expected student responses, teacher responses to the student's reactions, methods of evaluation and relevant notes.

Semi-structured interviews were composed of post-lesson discussions that the Lesson study group analyzed and evaluated the effectiveness of the research lessons thoroughly based on the observational data. The following questions guided post-lesson discussions.

1. What worked as planned during the research lesson?

2. What didn't work as planned?

3. Were there any pivotal moments surprising you that you observed during the instruction?

4. Were the lesson objectives met?

5. Do you think that overarching goal was obtained?

6. Would you change any of the planned activities or add new ones to achieve lesson objectives better?

The classroom observation sheet included background information about the research lesson, lesson period, student observation, and teacher notes. The participants were expected to record data indicating period and relevant activity, student observation data about the activities written on the sheet, and participants' reflections about them.

After each research lesson cycle, reflective journals documented data that the participants reflected on their own lesson study experience and their personal learning experiences. The participants were not limited with specific guiding questions or templates to collect as much data as possible.

Two focus group interviews were conducted with the participants, one of which was implemented after the pilot study, and the other was applied after the whole research process was over. The questions guiding focus group interviews were as follows.

1. Can you please comment on your lesson study experience?

2. What are the features of the Lesson Study process that you think is worthwhile or beneficial?

3. What are the features of the Lesson Study process that you think are negative?

4. Would you consider participating in a Lesson Study group in the future? Why /why not?

The data pool was subjected to analysis via Atlas. Ti Qualitative Data Analysis Software enables structuring a large volume of data, analyzing it systematically, and displaying the results with diagrammes and relations. As Friese (2011) suggested, computer-assisted qualitative data analysis consists of two levels of analysis, descriptive and conceptual level analysis. In descriptive level analysis, the main objective is to explore the data, look through them, notice relevant things with the research questions and develop a code list known as first stage coding. The data was studied extensively from this perspective by applying relevant literature, and a code list was created. Based on these first codes, the code list was developed further by noticing similarities and differences, merging the same codes with different labels or vice versa, and developing categories and themes. In this way, the data was structured and applied to the rest of the data, which is known as second stage coding

Later on, conceptual level analysis was conducted to investigate the data within the scope of research questions.

Validity in the present study was ensured by providing a detailed and thick description of the LS process (Wolcott, 1990; Maxwell, 1992). Additionally, subject matter expert opinion was also requested for each instrument to increase the internal validity of data collection tools. In addition, to triangulate the data, unstructured interviews, semi-structured interviews, classroom observational records, reflective journals, and focus group interviews were utilized.

The interrater agreement enables reliability in qualitative research, which calculates the agreement and consistency among the raters on the data sets. A strict reliability procedure was followed in the present study. First of all, the data sets were coded by the researcher. Then each code was given a number respectively. Another subject specialist coded the same data sets based on numbered reference codebook. Finally, the conformity between the two raters was analyzed by SPSS 23 Cohen's Kappa Statistics, the most common statistical analysis. The following table displays the relevant Cohen's Kappa Statistics. 
Table 2. Interrater Reliability Measures of Teacher Interventions Theme

\begin{tabular}{lrrrr}
\hline & $\begin{array}{c}\text { Value (Measure } \\
\text { of agreement, } \\
\text { Kappa) }\end{array}$ & $\begin{array}{c}\text { Asymptotic } \\
\text { Standardized } \\
\text { Errora }\end{array}$ & Approximate Tb & $\begin{array}{c}\text { Approximate } \\
\text { Significance }\end{array}$ \\
\hline Pilot Study Data &, 905 &, 021 & 48,531 &, 000 \\
RL 1 Data &, 886 &, 019 & 61,247 &, 000 \\
RL 2 Data &, 857 &, 025 & 49,716 &, 000 \\
RL 3 Data &, 816 &, 032 & 37,496 &, 000 \\
RL 4 Data &, 826 &, 035 & 33,834 &, 000 \\
Focus Group &, 817 &, 095 & 9,417 &, 000 \\
Interview Data & & & &, 000 \\
Post App &, 789 &, 083 & 13,561 & \\
Reflection Data & & & & \\
\hline
\end{tabular}

The table clearly illustrates that the conformity is "almost perfect" for the first six data sets except for post-application reflection sheets, which represent "substantial agreement" based on Landis and Koch's (1977) reference list. The coded data segments were revised, disagreements were identified, and necessary changes were executed on the data sets to increase conformity.

\section{RESULTS}

The findings are reported under two major headings: the impact of LS on the participating preservice ELT teachers' classroom management skills and the perceived impact of LS on each participant.

\section{The Impact of LS on Classroom Management Skills in terms of Teacher Interventions}

The diagram given below displays the semantic representation of the thematic analysis of the data. It includes the theme, category, and codes obtained from the data set and the groundedness and density of each code label. The groundedness displays the frequency count of codes, and density represents the association and linkages of each code label with the others. Although 28 code labels were referenced within the theme and 889 quotations were associated with them, the number was reduced to 13 in the following diagram since the codes with limited groundedness level were excluded from the diagram because of space concerns.

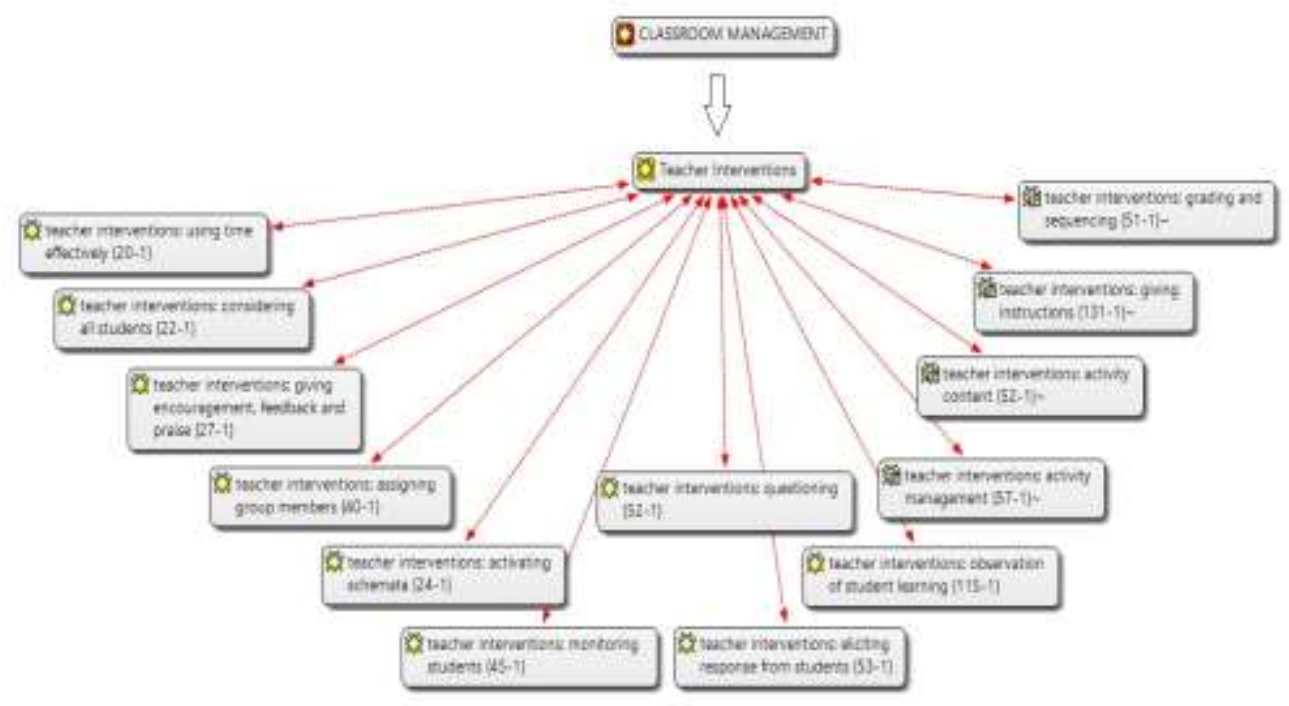

Diagram 2. Network View of Classroom Management Theme 
The results revealed that the impact had been observed in 28 dimensions at varying degrees of strength. The first code with the highest frequency count is "giving instructions." In other words, the most substantial impact has been observed in the dimension concerning giving instructions in the classroom. A total of 131 data segments out of 889 were linked to the relevant code. The number corresponds to $15 \%$ of the total number of quotations referenced with the codes within the theme.

The code that is ranked second in terms of frequency count is "observation of student learning." The number of quotations referenced with the "observation of student learning" code label is 115 , equal to $13 \%$ of the total number. In other words, 115 quotations were referenced with the code label "observation of student learning," which implies that it is the second most substantial impact based on the participants' perception.

The frequency count declines sharply in the following five code labels as represented in the diagram. These codes are "activity management" which has been referenced on 57 occasions, "eliciting response from students" that has been attached to 53 data segments, "questioning" which has been associated with 52 quotations, "activity content," whose frequency count is 52, and "grading and sequencing" whose number of occurrence is 51 . The percentage of each code label to the total number of associations is $\% 6$.

Because of the space concern, the other codes have not been discussed in detail as their perceived impact is limited and considered insignificant compared to those discussed above.

\section{The Impact of LS on Each Participants' Classroom Management Skills in terms of Teacher Interventions}

The following table displays the impact of LS on each participants' classroom management skills concerning teacher interventions. It includes the frequency count of each code label for each participant and their percentage based on the total number of data segments referenced with the codes.

Table 5. The Impact on Each Participants' Classroom Management Skills

\begin{tabular}{|c|c|c|c|c|c|c|c|c|c|c|c|c|}
\hline \multirow[t]{3}{*}{ Codes } & \multicolumn{12}{|c|}{ Participants } \\
\hline & \multicolumn{2}{|l|}{1} & \multicolumn{2}{|l|}{2} & \multicolumn{2}{|l|}{3} & \multicolumn{2}{|l|}{4} & \multicolumn{2}{|l|}{5} & \multicolumn{2}{|l|}{6} \\
\hline & $\mathrm{N}$ & $\%$ & $\mathrm{~N}$ & $\%$ & $\mathrm{~N}$ & $\%$ & $\mathrm{~N}$ & $\%$ & $\mathrm{~N}$ & $\%$ & $\mathrm{~N}$ & $\%$ \\
\hline activating schemata & 1 & 1 & 6 & 3 & 3 & 4 & 3 & 2 & 6 & 3 & 5 & 4 \\
\hline activity content & 12 & 10 & 7 & 3 & 1 & 1 & 11 & 9 & 15 & 8 & 4 & 3 \\
\hline activity management & 13 & 10 & 15 & 7 & 4 & 5 & 10 & 8 & 7 & 4 & 8 & 6 \\
\hline assigning group members & 7 & 6 & 10 & 5 & 5 & 6 & 8 & 6 & 6 & 3 & 4 & 3 \\
\hline attracting attention & 2 & 2 & 3 & 1 & 2 & 2 & $\mathrm{~N} / \mathrm{A}$ & 0 & 8 & 4 & 2 & 1 \\
\hline boredom-sameness & 2 & 2 & 8 & 4 & 2 & 2 & $\mathrm{~N} / \mathrm{A}$ & 0 & 2 & 1 & 1 & 1 \\
\hline managing behaviour & 2 & 2 & 2 & 1 & 1 & 1 & $\mathrm{~N} / \mathrm{A}$ & 0 & $\mathrm{~N} / \mathrm{A}$ & 0 & 4 & 3 \\
\hline considering all students & $\mathrm{N} / \mathrm{A}$ & 0 & 7 & 3 & 1 & 1 & 4 & 3 & 6 & 3 & 3 & 2 \\
\hline eliciting response from students & 5 & 4 & 20 & 10 & 2 & 2 & 9 & 7 & 9 & 5 & 6 & 4 \\
\hline error correction & $\mathrm{N} / \mathrm{A}$ & 0 & 3 & 1 & $\mathrm{~N} / \mathrm{A}$ & 0 & 1 & 1 & 4 & 2 & 4 & 3 \\
\hline establishing appropriate behavior & $\mathrm{N} / \mathrm{A}$ & 0 & 2 & 1 & $\mathrm{~N} / \mathrm{A}$ & 0 & $\mathrm{~N} / \mathrm{A}$ & 0 & 2 & 1 & $\mathrm{~N} / \mathrm{A}$ & 0 \\
\hline evaluation & 2 & 2 & 5 & 2 & 1 & 1 & 3 & 2 & 4 & 2 & 5 & 4 \\
\hline fun element & 2 & 2 & 11 & 5 & 4 & 5 & 5 & 4 & 4 & 2 & 7 & 5 \\
\hline $\begin{array}{l}\text { giving encouragement, feedback } \\
\text { and praise }\end{array}$ & 3 & 2 & 11 & 5 & 1 & 1 & 3 & 2 & 3 & 2 & 5 & 4 \\
\hline giving instructions & 16 & 13 & 19 & 9 & 10 & 12 & 23 & 18 & 40 & 21 & 19 & 14 \\
\hline grading and sequencing & 6 & 5 & 7 & 3 & 6 & 7 & 5 & 4 & 14 & 7 & 13 & 9 \\
\hline increasing motivation & 3 & 3 & 1 & 0 & 2 & 2 & 2 & 1 & 3 & 2 & 3 & 2 \\
\hline inductive teaching & $\mathrm{N} / \mathrm{A}$ & 0 & 1 & 0 & $\mathrm{~N} / \mathrm{A}$ & 0 & $\mathrm{~N} / \mathrm{A}$ & 0 & 2 & 1 & 2 & 1 \\
\hline input \& intake & 2 & 2 & 1 & 0 & 1 & 1 & 3 & 2 & 3 & 2 & 1 & 1 \\
\hline instructional strategy & 3 & 2 & 7 & 3 & $\mathrm{~N} / \mathrm{A}$ & 0 & 1 & 1 & 2 & 1 & 3 & 2 \\
\hline monitoring students & 10 & 8 & 7 & 3 & 9 & 11 & 6 & 5 & 5 & 3 & 7 & 5 \\
\hline more challenging tasks & 1 & 1 & 3 & 1 & 2 & 2 & $\mathrm{~N} / \mathrm{A}$ & 0 & 1 & 1 & $\mathrm{~N} / \mathrm{A}$ & 0 \\
\hline observation of student learning & 20 & 16 & 26 & 12 & 14 & 17 & 16 & 13 & 13 & 7 & 20 & 14 \\
\hline positive classroom atmosphere & 3 & 2 & $\mathrm{~N} / \mathrm{A}$ & 0 & 1 & 1 & $\mathrm{~N} / \mathrm{A}$ & 0 & $\mathrm{~N} / \mathrm{A}$ & 0 & 3 & 2 \\
\hline
\end{tabular}




\begin{tabular}{lllllllllllll}
\hline \multicolumn{1}{c}{ Codes } & \multicolumn{1}{c}{ Participants } & \multicolumn{1}{c}{} \\
& 1 & & 2 & & 3 & & 4 & & 5 & 6 \\
& $\mathrm{~N}$ & $\%$ & $\mathrm{~N}$ & $\%$ & $\mathrm{~N}$ & $\%$ & $\mathrm{~N}$ & $\%$ & $\mathrm{~N}$ & $\%$ & $\mathrm{~N}$ & $\%$ \\
\hline questioning & 3 & 2 & 18 & 9 & 6 & 7 & 8 & 6 & 10 & 5 & 8 & 6 \\
scaffolding & 3 & 2 & 3 & 1 & 1 & 1 & 3 & 2 & 1 & 1 & 1 & 1 \\
self-correction & $\mathrm{N} / \mathrm{A}$ & 0 & 5 & 2 & 1 & 1 & $\mathrm{~N} / \mathrm{A}$ & 0 & 6 & 3 & $\mathrm{~N} / \mathrm{A}$ & 0 \\
using time effectively & 1 & 1 & 2 & 1 & 2 & 2 & 2 & 1 & 11 & 6 & 2 & 1 \\
\hline TOTALS & 122 & 100 & 210 & 100 & 82 & 100 & 126 & 100 & 187 & 100 & 140 & 100 \\
\hline
\end{tabular}

As seen in the table, 122 quotations have been associated with the codes from Participant 1 's data, and four codes, "observation of student learning, giving instructions, activity content and activity management," respectively stand out based on their frequency count compared with the others.

It is evident that the code that has the highest frequency value is "observation of student learning." The code has been applied on 20 occasions, and the proportion of the total association is $16,3 \%$. In the excerpt below, we can see the participant's reflection on the benefits of LS experience drawing his/her attention to student learning rather than his/her instructional practices.

Before the Lesson Study process, I used to reflect on myself while teaching whether I could manage the instruction or not. However, I constantly observe students rigorously while giving instructions now. When I see a student who does not participate, I am thinking of ways to attract his/her attention in order to incorporate him/her into the lesson. I got this during this process.

Based on the frequency distribution, the code that is ranked second is "giving instruction." The code has been associated with 16 data segments that equal $13 \%$ of the total. The relevant association below illustrates the participant's heightened awareness about the importance of giving clear instructions.

It is vitally important for the students to give the instructions clearly before the activities. If possible, you should model what you want from the students (Ext. 2:54).

The importance of "activity management" and "activity content" were represented in the data sources of the majority of the participants. Therefore, the following code in the rank order is "activity management." It has been attached to 13 quotations from participant 1 's data, and the distribution percentage is $10 \%$. Similarly, the "activity content" code label was elicited in 12 instances, and the percentage of the association to the total is the same $(10 \%)$. In the following two quotes from participant 1, we can see his/her suggestions related to the management and content of the implemented activities in one of the research lessons.

Watching the warm-up activity only once did not have an expected impact on the students. The teacher should have replayed it and stopped the song to repeat the phrases by using body language (Ext. 28: 7)

In my opinion, we should change the implementation of the worksheet activity. The student should write the phrases themselves instead of matching them. (Ext. 30: 91)

Concerning Participant 2's findings, a total of 210 quotations were linked to the codes within the theme. Four codes, "observation of student learning, eliciting a response from students, giving instructions and questioning," have the highest frequency counts respectively compared with the others. The code with the highest frequency count is "observation of student learning," referenced in 26 instances. The percentage of the relevant association to the total is $12 \%$. The participant's heightened awareness of observing learners and ability to identify weaknesses and strengths is evident in the following quote.

A good teacher is also a facilitator and a good observer. He /she can easily determine the students' weaknesses and strengths during the course of instruction. (Ext.24: 15). 
The code that is ranked second is "eliciting response from students." The participant has referenced the code in 20 instances, as illustrated by the table, and the percentage of the association is $10 \%$. This is frankly evidenced in the following quotation from the participant's reflective diary entry after the pilot study cycle in which she commented on the impact of LS in her professional development.

In order to elicit responses from students, we may give clues to the students in order to help them. As an example, we can give two options to the students, and we may ask them to choose one and say it if it is too hard for them to produce what we have taught. Giving clues in order to elicit responses from students is one of the most important criteria in English language teaching (Ext.29:39, 24: 9).

The code ranked third is "giving instructions as visualized by Table 6. As in the previous partner, the code is the other code that has been associated with Participant 2 's data segments most frequently. It has been attached to 19 quotations, and the number corresponds to $9 \%$ of the total quotation number. During the post-lesson discussion after the first research lesson, the participant expressed his/her opinion about giving instructions, although the other participants disagreed, stating that the instructions should be accompanied by body language. We can see the participant's opinion concerning "giving instructions" in the following quote.

We should leave some space for students' creativity. For example, it is not necessary to give instructions for the warm-up activity "Move and Freeze." Everything is very clear on the screen (Ext.19:84).

The fourth code in rank order is "questioning," as displayed by the table. Eighteen quotations were selected from Participant 2's data to associate with the "questioning" code, which corresponds to \% 9 of the total associations with the codes within the theme. The participant's heightened awareness of questioning was visible in many cases. An excerpt from the reflective sheet after the second research lesson below provides an example.

When teachers ask a question, they should choose the volunteer students first, then the shy ones, in order not to make them feel inhibited. Calling the students with their names is the best solution to ensure a positive atmosphere in the class, so teachers should try to keep their names in their minds. (Ext.35: 12).

Concerning Participant 3's findings, it is possible to see similar distribution when compared with the previous two partners, as illustrated by Table 6 . The number of quotations that have been referenced with the codes within the classroom management theme is 82 . The total number of three codes that have been coined as "observation of student learning, giving instructions and monitoring students," respectively constitute $40 \%$ of the total code-quotation association within the theme.

It is visualized in the table that the code that has the highest frequency count is "observation of student learning," which has been referenced 14 times. The frequency percentage of the association to the total is \% 17. The participant showed evidence of increasing ability to observe students during the process, especially by the accounts from classroom observation sheets, lesson planning and post lesson discussions, and reflective diary entries. Accounts of increasing consciousness about observational skills were noted when the participant evaluated the whole process during focus group interviews. The quote below shows the participant's reflection of the LS process during the focus group interview conducted after the pilot study.

Thanks to the LS process that I can better see the backstage of preparing a lesson plan and also determining English learners' problems by observing them (Ext.25: 1).

Another frequently recorded impact on the participant's classroom management skills was observed in the "giving instructions" code as in the previous partners. It is the second code in the rank 
order is as illustrated by Table 6 . The code has been referenced in 10 instances whose frequency count corresponds to $12 \%$ of the total. The participant constantly referred to increasing self-confidence in teaching as the LS process contributed to teacher learning significantly in various classroom management strategies, as illustrated in the following quote.

Also, I feel like I have become very good at managing the classroom and students. I am very careful of questioning, giving instructions, planning the lesson, my body language, and using the classroom time effectively. (Ext.73: 6).

The grounded structure of LS based on close observations of student behaviours led to the realization of looking into students more critically, especially those who might have remained disengaged in the background. In this respect, the following code in the rank order based on frequency count is "monitoring students." The number of associations is nine, and the percentage of association is $11 \%$ when it is proportioned to the total number of associations obtained from Participant 3's data sets. Excerpt from the participant's post-application documents that he/she commented on the aspects of LS contributing to his/her development as a teacher provides an example.

I am constantly watching myself while I am lecturing in the classroom and also monitoring students at the same time. If I see that a group of students does not understand the lesson, a student disengaged, or some students are dealing with other things, I just think about my practices and try to figure out the reason behinds the students' lack of understanding. Is it because of my instructions, is it because of my teaching style or instructional strategies, etc... (Ext.73: 1).

Concerning Participant 4's findings concerning the impact of LS on classroom management strategies, it was observed that similar codes stand out based on frequency count from Participant 4's data that has been referenced with the codes on 126 occasions within the theme. All data sources revealed heightened awareness in terms of "giving instructions as shown in Table 6 that the code label has the highest frequency number compared with the other codes. Of 126 quotations referenced with the themes' codes, $18 \%$ of the total was associated with the "giving instruction" code label whose frequency count is 23 . The following extract documented from the participant's reflective diary after implementing the first research lesson cycle reflects a deeper appreciation for the importance of giving instruction.

Applying prepared narrative into the lesson was effective in terms of drawing students' attention, but expected student participation could not be achieved because giving instruction and purpose to students before the activity was incomplete. In this sense, the importance of instruction should be taken into account for the next studies. (The participant is associating the fail in the implementation of activity to not being able to give instructions) (Ext.22: 10).

The second code based on frequency count is "observation of student learning," as observed similarly in the previous partners' findings. The code has recurred in 16 instances which correspond to $13 \%$ of the total. The relevant code-quotation association has been exemplified in the following extract.

Students seem puzzled, like they dont have any purpose. They are trying to figure out what is going on and what they are going to do. (The participant's written observation record of RL 1) (Ext.27: 12).

The frequency declines sharply in the following codes so that they have not been discussed in detail. Participant 5's findings are quite distinctive when compared with the other participants. The number of quotations that have been referenced with the codes within the classroom management theme is 187. One code label giving instructions" has the highest frequency count, and it constitutes more than one-fifth of the total. The number of quotations that have been associated with the code is 40 , and it is equal to $21 \%$ of the total number that is 187, as mentioned before. LS's student learningoriented nature paved the way for collaborative learning in various classroom management strategies, 
especially in developing skills for giving instructions. In the following extract documented from the postlesson discussion of the first research lesson, the participant attributes the failure of planned activity to the lack of instructions.

We can give instructions in a simpler way. We can act out the instruction while giving it. As an example, I will say, I will play the tape, and you will start moving. I will act it out there to show students what to do, and I will tell them that you will freeze when it stops and I will stop moving (The participant is suggesting to apply the planned activity in a more efficient way during RL 1 post-lesson discussion (Ext.19: 83).

The following codes in the rank order are "activity content," "grading and sequencing," and "observation of student learning," as displayed by Table 6, but they are not significant in terms of frequency count, although they represent similar distribution with the other partner's findings.

The findings obtained from Participant 6's data represented a similar pattern with the previous five partners' data sets, as illustrated by table 6 . The total number of code-quotations associated with the classroom management theme codes obtained from Participant 6's data sources is 140. Two codes stand out based on the frequency distribution of codes as given in Table 6, and they are "observation of student learning" and "giving instructions" code labels, respectively, as expected.

The code applied most frequently is "observation of student learning," as mentioned before. The number of data segments that have been referenced with the code is 20 , and the percentage of the association to the total is $14 \%$. The following code ranked second in terms of frequency distribution is "giving instruction," referenced on 19 occasions. The following two extracts are representative of the associations between the given code aforementioned and related data.

By virtue of LS, I have increased my awareness of how to observe students in the classroom and determine their weaknesses and strength. (Ext.21: 17).

I will try to do my best to give instructions in English before each activity, but I believe their language proficiency matters there. I will observe them check their understanding. If I realize that they are puzzled, I will switch to Turkish to give them. (The participant is stating how to apply each activity during a lesson planning meeting for RL 3), (Ext.30: 83).

To sum up, concerning the impact of the LS process on the participants' classroom management strategies, "observation of student learning" and "giving instructions" codes were applied to the data segments most frequently among all partners. Also, the codes "activity management" and "activity content" were most frequently used by most participants when it comes to lesson planning and implementation.

\section{DISCUSSION}

The present study aimed to investigate if LS impacted the classroom management skills of the preservice ELT teachers, which had been reported as the major challenge for the pre-service teachers (Balli, 2011; Reupert \& Woodcock, 2010). The findings revealed that Lesson Study provides a reformist professional development opportunity for the pre-service teachers to practice various classroom management strategies in a variety of actual classroom settings. Within this perspective, the study corroborates with the existing research suggesting that LS has contributed to the teachers' classroom management skills and enhances efficient classroom management (Angelini \& Alvarez, 2018; Schipper, Goei, de Vries, \& van Veen, 2018).

The findings revealed that the Lesson Study process triggered 28 critical classroom management interventions, which had varying degrees of impact on the participating pre-service teachers. Although the list may seem extensive, LS intervention has caused a significant impact on the six major dimensions.

First of all, LS created a new perspective for pre-service teachers in which they were more inclined to position the learners in the center of the learning process. During the observation of RLs, they constantly reflected on the challenges against learning and thus focused more on student learning in 
planning and replanning, teaching, analysis, and revisions of the RLs. In this respect, it can be argued that LS caused a significant change in the participating pre-service teachers' beliefs as we observed a shift from teaching per se towards student learning thanks mainly to the student learning oriented nature of LS procedure (Cerbin \& Kopp, 2006; Fernandez \& Robinson, 2006; Lewis, 2000; Marble, 2006; Murata \& Pothen, 2011).

LS implementation also helped pre-service teachers realize the importance of giving clear and concise instructions and explanations. LS provided opportunities for the participants to critically reflect on the obstacles of student learning during lesson planning meetings and post-lesson discussions ( \& Walsh, 2009). Of particular importance, the process generated motivation and awareness to read scientific studies on how to give clear instructions in the classroom. In this sense, LS intervention helped the participants identify their flaws in their pedagogical knowledge and provided an ideal ground to remedy them.

Additionally, it is widely known that collaborative lesson planning is a crucial component of the LS procedure. This study brought about instructional improvement as the process directed the participants' attention to the content and management of the planned activities during the implementation of the research lessons (Lewis, Perry, Friedkin, \& Roth, 2012; Marble, 2006; Fujii, 2014). LS process provided ample opportunity for the pre-service teachers to investigate how the students learned a specific learning item and be encouraged to develop creative lesson plan and content that responds to students' needs. The re-application of the same research lessons and its ongoing, repeated cycles promoted coming up with unique ideas for the lesson plans and using them as research lesson content. Similarly, the re-application of the research lessons in different contexts enabled them to observe how the collaboratively created lesson plan was delivered to students, adapted, and managed by them to respond to diversified students' needs. After each research lesson cycle, post-lesson discussions promoted instructional strategies' development as they forced pre-service teachers to critically reflect on the delivery and management of the tasks and activities. The LS process guided participants in what to teach and how to teach (Cerbin \& Kopp, 2006; Cajkler, Wood, Norton, \& Pedder, 2014; Pothen \& Murata, 2008).

\section{CONCLUSION}

LS is a valuable tool responding to the limitations of traditional teacher education programs, which have been reported to be rich in theoretical knowledge but deficient in practical experience (Zeichner \& Liston, 1987). Incorporating LS into teacher training programs would help prospective teachers bridge the gap between theory and practice.

LS also offers an invaluable opportunity for the prospective teachers to deal with widely reported issues such as dependence on textbooks, lack of classroom management skills, incapability in lesson planning, centering on student control rather than student learning (oberts, 1998). As well as having access to a variety of meaningful, collaborative onsite, real learning experiences, engaging in LS also helped pre-service teachers enhance their skills in crafting a lesson plan thanks to the iterative process in planning a lesson imposed by LS procedure, sharpen their awareness of the obstacles in front of student learning, develop several classroom management strategies and divert their attention from student control to student learning.

The study had a few limitations. The first limitation of the present study stems from the nature of the LS procedure. The implementation of research lessons in classrooms with six pre-service teachers, one researcher, and one outside observer caused students a certain degree of distraction. In order to minimize the constraint and mitigate the effect, classroom teachers informed the students about the research lesson before the implementation to lower their defenses.

The second limitation arises from the nature of qualitative research design. The present study was conducted with six pre-service ELT teachers studying at a state university in Turkey. In this respect, the findings cannot be extended or generalized to a wider population or different contexts. In this respect, further studies in different contexts with more participants are needed to validate the research findings.

The present study reveals the findings concerning the participants ' perception of the impact of Lesson Study intervention on their classroom management skills. Follow-up studies might 
investigate the participants' actual teaching practices to validate if LS has caused improvement in teaching practices rather than changes in the perception.

\section{Funding and Conflicts of Interest}

The author declares that there is no funding and conflicts of interest for this research.

\section{REFERENCES}

Adler, S. A. (1991). The reflective practitioner and the curriculum of teacher education. Annual Meeting of the Association of Teacher Educators. Las Vegas.

Allen, J. M. (2009). Valuing practice over theory: How beginning teachers re-orient their practice in the transition from the university to the workplace. Teaching and Teacher Education, 647-654.

Angelini, L. M., \& Alvarez, N. (2018). Spreading lesson study in pre-service teacher instruction. Journal for Lesson and Learning Studies.

Baker, C., Gentry, J., \& Larmer, W. (2016). A model for online support in classroom management: Perceptions of beginning teachers. Administrative Issues Journal, 22-37.

Balli, S. J. (2011). Pre-service teachers' episodic memories of classroom management. Teaching and Teacher Education, 245-251.

Bassey, M. (1999). Case study research in educational settings. Philadelphia: Open University Press.

Cajkler, W., Wood, P., Norton, J., \& Pedder, D. (2014). Lesson Study as a vehicle for collaborative teacher learning in a secondary school. Professional Development in Education, 511-529.

Cerbin, B. (2011). Lesson study: Using classroom inquiry to improve teaching and learning in higher education. Sterling, Virginia: Stylus Publishing.

Cerbin, W., \& Kopp, B. (2006). Lesson Study as a model for building pedagogical knowledge and improving teaching. International Journal of Teaching and Learning in Higher Education, 250257.

Christofferson, M., \& Sullivan, A. L. (2015). Preservice teachers' classroom management trainıng: A survey of self-reported trainıng experiences, content coverage, and preparedness. Psychology in the Schools, 248-264.

Crandall, J. (2000). Language teacher education. Annual Review of Applied Linguistics, 34-55.

Creswell, J. (2012). Qualitative inquiry research design. Choosing among five approaches. London: Sage Publications.

Creswell, J. W. (2014). Research design. Qualitative, quantitative, and mixed-method approaches. London: Sage.

Denzin, N. K., \& Lincoln, Y. S. (Eds.). (2018). The sage handbook of qualitative research (Fifth ed.). London.

Desforges, C. (2015). Lesson study as a strategic choice for CPD. In P. Dudley (Ed.), Lesson Study: Professional Learning for our time (pp. 16-20). New York: Routledge.

Dicke, T., Elling, J., Schmeck, A., \& Leutner, D. (2015). Reducing reality shock: The effects of classroom management skills training on beginning teachers. Teaching and Teacher Education, 1-12.

Dudley, P. (2011). Lesson study: A handbook. Retrieved 2016, from lessonstudy.co.uk/wp.../newhandbook-revisedMay14.pdf.

Dudley, P. (Ed.). (2015). Lesson study: Professional learning for our time. New York: Routledge.

Duff, P. A. (2008). Case study research in applied linguistics. New York: Taylor Francis. 
Eisenman, G., Edwards, S., \& Cushman, C. A. (2015). Bringing reality to classroom mnagement in teacher education. The Professional Educator, 39(1), 1-12.

Ertle, B., Chokshi, S., \& Fernandez, C. (n.d.). A Tool for Planning and Describing Study Lessons1. Retrieved from https://sarahbsd.files.wordpress.com/2014/09/lesson_planning_tool.pdf

Fernadez, C., \& Yoshida, M. (2004). Lesson study: A Japanese approach to improving mathematics teaching and learning. Mahwah, NJ.: Lesson study: A Japanese approach to improving mathematics teaching and learning.

Fernandez, M. L. (2010). Investigating how and what prospective teachers learn through microteaching lesson study. Teaching and Teacher Education, 351-362.

Fernandez, M. L., \& Robinson, M. (2006). Prospective teachers' perspectives on microteaching lesson study . Education, 203-215.

Flower, A., McKenna, J. W., \& Haring, C. D. (2017). Behavior and classroom management: Are teacher preparation programs really preparing our teachers? Preventing School Failure: Alternative Education for Children and Youth, 163-169.

Fraenkel, J. R., Wallen, N. E., \& Hyun, H. H. (2012). How to design and evaluate research in education (Vol. 8). New York: McGraw-Hill.

Freeman, D. (2002). The hidden side of the work: Teacher knowledge and learning to teach. Language Teaching, 1-13.

Friese, S. (2011). Qualitative data analysis with Atlas.ti. London: Sage Publications.

Fujii, T. (2014). Implementing Japanese lesson study in foreign countries: Misconceptions revealed. Mathematics Teacher Education and Development.

Hammerness, K. (2011). Classroom management in the United States: A View from New York City. Teaching Education, 151-167.

Hanfstingl, B., Abuja, G., Isak, G., Lechner, C., \& Steigberger, E. (2018). Continuing professional development designed as second-order action research: Work-in-progress. Educational Action Research, 1-11.

Hanfstingl, B., Rauch, F., \& Zehetmeier, S. (2019). Lesson study, learning study and action research: Are there more differences than a discussion about terms and schools? Educational Action Research, 455-459.

Hargreaves, A. (1994). Changing teachers, changing times. New York: Teachers College Press.

Hoy, A. W., \& Weinstein, C. (n.d.). Student and teacher perspectives on classroom management. In C. M. Evertson, \& C. S. Weinstein (Eds.), Handbook of classroom management: Research, practice, and contemporary issues (pp. 181-219). Lawrence Erlbaum Associates Publishers.

Hudson, M. E., Voytecki, K. S., Owens, T. L., \& Zhang, G. (2019). Pre-service teacher experiences implementing classroom management practices through mixed-reality simulations. Rural Special Education Quarterly, 79-94

Johnson, K. (2006). The sociocultural turn and its challenges for second language teacher education. Tesol Quarterly, 235-257.

Jones, V. (2006). How do teachers learn to be effective classroom managers? In C. M. Evertson, \& C. S. Weinstein (Eds.), Handbook of classroom management: Research, practice, and contemporary issues (pp. 887-907). Lawrence Erlbaum Associates Publishers.

Kang, M., \& Cavanagh, M. S. (2018). Classroom ready? Pre-Service teachers' self-efficacy for their first professional experience placement. Australian Journal of Teacher Education, 43(7).

Landau, B. (2001). Teaching classroom management: A stand-alone necessity for preparing new teachers. Annual Meeting of the American Educational Research Association. Seattle: Eric. 
Landis, J. R., \& Koch, G. G. (1977). An application of hierarchical Kappa-type statistics in the assessment of majority agreement among multiple observers. International Biometric Society, 363-374.

Leavy, A. M., \& Hourigan, M. (2016). Using lesson study to support knowledge development in initial teacher education: Insights from early number classrooms. Teaching and Teacher Education, 161-175.

Lewis, C. (2000). Lesson study: The core of Japanese professional development. Paper presented at the American Educational Research Association (2000 Annual Meeting). New Orleans.

Lewis, C. C., Perry, R. R., Friedkin, P., \& Roth, J. R. (2012). Improving teaching does improve teachers: Evidence from lesson study. Journal of Teacher Education, 368-375.

Lewis, C., \& Hurd, J. (2011). Lesson study step by step: How teacher learning communities improve instruction. Portsmouth: Heinemann.

Marble, S. T. (2006). Learning to teach through lesson study. Action in Teacher Education, 86-96.

Martin, S. D. (2004). Finding balance: impact of classroom management conceptions on developing teacher practice. Teaching and Teacher Education, 405-422.

Maxwell, J. A. (1992). Qualitative research design: An interactive approach. Thousand oaks, California: Sage Publications.

Murata, A., \& Pothen, B. (2011). Lesson study in pre-service elementary mathematics methods courses: Connecting emerging practice and understanding. In L. C. Hart, A. Alston, \& A. Murata (Eds.), Lesson study research and practice in mathematics education (pp. 103-116). Dordrecht: Springer.

Poulou, M. (2007). Student-teachers' concerns about teaching practice. European Journal of Teacher Education, 91-110.

Reupert, A., \& Woodcock, S. (2010). Success and near misses: Pre-service teachers' use, confidence and success in various classroom management strategies. Teaching and Teacher Education, 12611268.

Richards, C. J. (2008). Second language teacher education today. Relc Journal, 158-177.

Richards, C. J., \& Farell, S. C. (2005). Professional development for language teachers. Strategies for teacher learning. New York: Cambridge University Press.

Richards, J. C. (1990). The dilemma of teacher education in second language teaching. In J. C. Richards, \& N. David (Eds.), Second Language Teacher Education (pp. 3-16). Cambridge: Cambridge University Press.

Ritchie, J., \& Lewis, J. (Eds.). (2003). Qualitative research practice. A guide for social science students. London: Sage Publications.

Roberts, J. (1998). Language teacher education. London: Arnold.

Schipper, T., Goei, S. L., de Vries, S., \& van Veen, K. (2018). Developing teachers' self-efficacy and adaptive teaching behaviour through lesson study. International Journal of Educational Research, 109-120.

Siebert, C. J. (2005). Promoting pre-service teachers' success in classroom management by leveraging a local union's resources: A professional development school initiative. Education, 385-392.

Sims, L., \& Walsh, D. (2009). Lesson study with pre-service teachers: Lessons from lessons. Teaching and Teacher Education, 724-733.

Sri Kanthan, G. (2011). MSC science communication project report: Stregthening student engagement in the classroom. Singapore: National University of Singapore. 
Stoiber, K. C. (1991). The effect of technical and reflective pre-service instruction on pedagogical reasoning and problem solving. Journal of Teacher Education, 131-139.

Theelen, H., van den Deemt, A., \& den Brok, P. (2018). Classroom simulations in teacher education to support pre-service teachers' interpersonal competence: A systematic literature review. Computers \& Education, 14-26.

Wesley, D. A., \& Vocke, D. E. (1992). Classroom discipline and teacher education. Annual Meeting of the Association of Teacher Educators. Orlando: Eric.

Wolcott, H. E. (1990). Writing up qualitative research. Newbury Park CA: Sage Publications.

Yalçın Arslan, F. (2019). The role of lesson study in teacher learning and professional development of EFL teachers in Turkey: A case study. TESOL Journal, 1-13.

Yin, R. K. (2009). Case study research. Design and methods (4 ed., Vol. 5). London: Sage Publications.

Zeichner, K. M., \& Liston, D. P. (1987). Teaching student teachers to reflect. Harvard Educational Review, 23-48. 